\title{
Therapeutic trajectories of children attending a Children Psychosocial Care Center
}

How to cite this article: Cardoso CS, Coimbra VCC, Andrade APM, Martins MFD, Guedes AC, Pereira VR. Therapeutic trajectories of children attending a Children Psychosocial Care Center. Rev Gaúcha Enferm. 2020;41:e20190166. doi: https://doi.org/10.1590/19831447.2020.20190166
Universidade Federal de Pelotas (UFPel), Faculdade de Enfermagem, Programa de Pós-Graduação em Enfermagem. Pelotas, Rio Grande do Sul, Brasil.

- Universidade Estadual do Centro Oeste (Unicentro), Departamento de Psicologia. Irati, Paraná, Brasil.

Universidade Federal de Pelotas (UFPel), Faculdade de Pedagogia. Pelotas, Rio Grande do Sul, Brasil.
Trajetórias terapêuticas das crianças que frequentam um Centro de Atenção Psicossocial Infantojuvenil

Trayectorias terapéuticas de niños vinculado a un Centro de Atención Psicosocial Infanto Juvenil

\section{Clarissa de Souza Cardoso ${ }^{a}$ Valéria Cristina Christello Coimbra ${ }^{a}$ Ana Paula Muller de Andrade ${ }^{b}$ Maria de Fátima Duarte Martins ${ }^{c}$ Ariane da Cruz Guedes ${ }^{\mathrm{a}}$ Viviane Ribeiro Pereira ${ }^{a}$}

\section{ABSTRACT}

Objective: To describe the unique therapeutic trajectories of children linked to a Center for Psychosocial Child and Adolescent Care (Centro de Atenção Psicossocial Infantojuvenil, CAPSi).

Method: A qualitative, descriptive and exploratory research. Data collection was carried out with five school-age children, linked to a Child and Adolescent Psychosocial Care Center (CAPSi), located in the South of Rio Grande do Sul (RS), from April to July 2016, from the consultation to the chart, observation, field journal entries and by the narrative interviews, which were transcribed and submitted to narrative analysis. The narrative interviews mediated by the ludic instrumental called Map of the Five Fields (MFF) allowed for oral expression.

Results: Two themes were constructed: "characterization of children participating in the research" and "singular therapeutic trajectories of children".

Conclusion: The therapeutic trajectories made it possible to present the uniqueness of the life of the participants, through the relation established between the child, the territory in which he/she transits and the social context.

Keywords: Child health. Mental health. Child care.

\section{RESUMO}

Objetivo: Descrever as trajetórias terapêuticas singulares de crianças vinculadas a um Centro de Atenção Psicossocial Infantojuvenil (CAPSi).

Método: Pesquisa qualitativa, descritiva e exploratória. A coleta de dados ocorreu com cinco crianças em idade escolar vinculadas a um Centro de Atenção Psicossocial Infantojuvenil (CAPSi) localizado no sul do Estado do Rio Grande do Sul (RS), no período de abril a julho de 2016, a partir da consulta ao prontuário, da observação, das anotações em diário de campo e da entrevista narrativa, as quais foram transcritas e submetidas à análise narrativa. As entrevistas narrativas, mediadas pelo instrumento lúdico chamado Mapa dos Cinco Campos (MCC), permitiram a expressão oral.

Resultados: Foram construídos dois temas: "Caracterização das crianças participantes da pesquisa" e "Trajetórias terapêuticas singulares das crianças".

Conclusão: As trajetórias terapêuticas possibilitaram apresentar a singularidade de vida das participantes por meio da relação estabelecida entre a criança, o território por onde ela transita e o contexto social.

Palavras-chave: Saúde da criança. Saúde mental. Cuidado da criança.

\section{RESUMEN}

Objetivo: Describir las trayectorias terapéuticas singulares de niños vinculados a un Centro de Atención Psicosocial Infantojuvenil (CAPSi).

Método: Investigación cualitativa, descriptiva y exploratoria. Se recolectaron datos de cinco niños en edad escolar, vinculados a un Centro de Atención Psicosocial Infantojuvenil (CAPSi), ubicado en el sur de Rio Grande do Sul (RS), en el período de abril a julio de 2016, a partir de consultas a la historia clínica, de la observación, de las anotaciones en el diario de campo y por medio de entrevistas narrativas, las cuales fueron transcritas y sometidas a análisis narrativo. Las entrevistas narrativas mediadas por el instrumento lúdico llamado Mapa de los Cinco Campos (MCC) permitieron la expresión oral.

Resultados: Se elaboraron dos temas: "caracterización de los niños participantes de la investigación" y "trayectorias terapéuticas singulares de los niños".

Conclusión: Las trayectorias terapéuticas permitieron presentar la singularidad de la vida de los participantes, a través de la relación establecida entre el niño, el territorio a través del cual transita y el contexto social.

Palabras clave: Salud del niño. Salud mental. Cuidado del niño. 


\section{口INTRODUCTION}

Therapeutic trajectories mean the path taken throughout the life of each person in the search for better conditions of assistance, treatment and health rehabilitation ${ }^{(1)}$. In this sense, it is understood that the trajectory, when carried out, involves three important dimensions: the individual, in this case, the child; the territory, and the life context ${ }^{(1)}$ For this reason, the focus of this work is the Singular Therapeutic Trajectories (STTs), i.e., the articulation of these three dimensions, child-territory-context, necessary because they allow reflecting on the production of the child's individuality, stating that it plays a role important in social construction ${ }^{(2)}$.

The territory is considered beyond its physical and geographical limits, because it is the feeling of belonging to the place, it is the basis for work, for housing, because it allows for the realization of "material and spiritual exchang$\mathrm{es}^{\prime \prime(3)}$. For this reason, it is understood that the territory is an important concept for the development of work in Mental Health, since it is constituted through the experiences of the individuals crossed by the relationships built between people and institutions.

Acknowledging the existence of the STTs implies knowing and recognizing the work carried out by the Psychosocial Care Center for Children and Adolescents (Centro de Atenção Psicossocial Infantojuvenil, CAPSi), the main care tool of the Psychosocial Care Network (Rede de Atenção Psicossocial, RAPS), as it promotes rehabilitation based on important information like experiences, beliefs, and values that constitute the child's individuality in the territory ${ }^{(1-4)}$.

The CAPSi favors the care of children and adolescents from three to 18 years old with severe and persistent mental disorders that interfere in the satisfactory development of the abilities and skills of this public, such as: severe depression, psychosis, severe anxious conditions and chemical dependence. It is possible that these cases present comorbidities, such as conduct disorder, self-mutilation, eating disorders and Attention Deficit and Hyperactivity Disorder (ADHD). Activities are offered through groups, therapeutic workshops, home visits, individual care and family care.

The CAPSis have the function of establishing partnerships with different services of the care network and of the Affective Social Network (Rede Social e Afetiva, RSA), in addition to other sectors, such as education, social assistance, justice and leisure, because they enable the expansion of assistance and guarantee a care in freedom ${ }^{(5-6)}$.

The RSA is considered a network of relationships that are represented by the family, school, community, and services like the CAPSi. The social and affective support offered by this network is essential to manage adverse moments and situations of social abandonment, promoting bonds and the development of the subjective well-being of children throughout their lives ${ }^{(1)}$.

This research was guided by the principles of the Psychiatric Reform (PR) ${ }^{(6)}$ in order to consider the child's role, from the construction of his participation as an individual of rights ${ }^{(7)}$. Thus, this study is justified in order to strengthen the public policies in the area of mental health for children and adolescents because it prioritizes the demands of the child and allows for a broader view of mental health needs.

The redirection of the mental health policy for children and adolescents provides a different look at the STTs, listing a care that is dedicated to this public and its singularities ${ }^{(2)}$. In this sense, the objective of this study was to describe the singular therapeutic trajectories of children linked to a Psychosocial Care Center for Children and Adolescents (CAPSi).

\section{$\square$ METHOD}

This is a descriptive and exploratory research, with a qualitative approach, which values the cognitive construction of the experience, supporting a critical analysis that needs to be consolidated collectively, seeking to know its relations and institutions ${ }^{(8)}$. This type of research allowed describing and exploring children's STTs in the search for mental health care.

The study was carried out in a Psychosocial Care Center for Children and Adolescents (CAPSi), in a small municipality located in the south of Rio Grande do Sul (RS), from April to July 2016. It is a regionalized service, in operation since 2006, which, in its physical structure, has a reception, five individual service rooms, a room for meetings and group activities, a kitchen, two bathrooms and a courtyard. The multidisciplinary team consists of a pediatric doctor with a specialization in Mental Health, four psychologists, a social worker, a nurse, three pedagogues, a therapeutic companion, a nursing technician, two bureaucrats, general service professional and a driver. The rooms have tables, chairs and cabinets, colored pencils, colored pens, crayons, papers, games and some toys. One of the individual attendance rooms was offered by the service for research activities as it is a more private space, with a low noise level, which allowed for clear recordings. The child's privacy during the interview is also guaranteed.

The professionals working in the service were asked to indicate children to be chosen based on the following inclusion criteria: school-age children of both genders, who were linked to the service for at least six months to ensure the construction of the STTs and those that allow for the use of the recorder. Children with great cognitive and language limitations were excluded due to the inability to respond to the activity. 
The participants were five children who met the inclusion criteria, and the justification for this sample is due to the theoretical saturation of the data. In the qualitative research, singularities and meanings are sought from the sociocultural dimension that is expressed through "beliefs, values, opinions, representations, forms of social relations, symbologies, uses, customs, behaviors, and practices ${ }^{\prime \prime(8)}$.

Data collection was carried out by consulting the medical records to find out how long they had been connected to the service, the referrals made prior to the researcher's arrival to other services and which medications were prescribed. Observing the service allowed following the routine of the activities performed by various professionals, an observation performed from the reception, psychological consultation of the women participating in the study, groups, workshops and home visits. The notes in the field diary during the collection made a significant contribution to the systematic composition of the STTs through the description of the activities carried out and the lines of care established for each of the participating children. Finally, the narrative interview was used ${ }^{(9)}$, mediated by the use of a playful instrument called Five Field Map (FFM) ${ }^{(10)}$, as a strategy to favor oral expression during the research ${ }^{(9-12)}$. An interview script with two open questions was used: "Who is the person you feel you can count on, with whom you feel safe?" and "Which situation makes you insecure and/or anxious?". To make the individual interview operational, an instrument made of felt with concentric circles and the dolls that represented the people in the social and affective network of each participating child were availed to each of them.

For a complete and accurate record of the individuals' statements, the interviews were recorded in audio with the aid of a digital recorder.

Data were analyzed following the stages of the narrative analysis ${ }^{(9)}$. The interviews were transcribed and then the material was read in two propositions: indexed material corresponding to the concrete references (who, where and why) and non-indexed material that expressed the judgments of values, beliefs and the wisdom of life. Then, the indexed and non-indexed material of each participant was analyzed to compose the singular trajectories and, afterwards, the material was compared, identifying which similarities existed in the constructed paths, composing the collective trajectories.

The research was approved by the Ethics and Research Committee of the Faculty of Nursing of the Federal University of Pelotas, in 2016, under opinion No.1,455,727 and respected all aspects contained in Resolution 466/12 of the National Health Council(13). Still in compliance with this resolution, the child's legal guardian signed the Informed Consent Form (ICE) and the child, the written consent. The anonymity of the participants was maintained at all times and, for that, the initial of child (C) was adopted followed by the number corresponding to the interview $(\mathrm{C} 1, \mathrm{C} 2, \mathrm{C} 3, \mathrm{C} 4, \mathrm{C} 5)$.

\section{RESULTS}

\section{Characterization of the children participating in the research}

Of the five participating children, two were male and three female, aged between eight and 11 years old. Regarding the length of the time linked to the service, there was a variation of two to six years. Regarding the reasons that led them to look for the service, most of them had been referred by the school. One of the participants received referral to the CAPSi from a neighboring municipality and another spontaneously sought the service.

Regarding the evasion of the service, only one of the participants did not have a history of absence, while the others had evaded at least once, returning to the CAPSi many times after 12 months or more.

Most of the time, the monitoring of these children was carried out in partnership with other components of the network, such as the Tutelary Council, the Childhood Prosecutor's Office, the Family Health Strategy (FHS) and the Social Assistance Reference Center (Centro de Referência da Assistência Social, CRAS). The inter-institutional partnership was built in a more effective way related to the situations that permeated each case.

At the time of the research, only one of the children participated in the groups offered by the CAPSi and two of them were residents of the rural area, which hindered access. However, the others lived in the urban area, which allowed for an easier access to the service and yet, they did not participate in the groups.

Another fundamental issue was related to the fact that most of them used some type of psychiatric drug for the symptoms attributed to the diagnosis received. Only one of the children was not being treated with psychiatric medication.

\section{Singular Therapeutic Trajectories of the children}

The graphic representations explain their life stories from birth, joining the CAPSi, until the present moment. It is noteworthy that the STTS were built from the participants' point of view about the people who made up and/or participated in their lives, with emphasis on the family nucleus, the school and the CAPSi. The narrative was represented by illustrative 
figures that show the STT of each child in the social and affective network, considering their uniqueness, as shown in the figures.

The STTs allowed for the recognition of specific characteristics of each child when going through the care network, revealing that the resources available for mental health care are crossed by an asylum knowledge, such as the existence of a correlation between medicalization and the distancing of parents in relation to children, making it easier to control children's concerns through medication than trying to understand these manifestations. The five participants were assigned their diagnoses and, by observing the manifestations and presence of the symptoms, a comparison was made with those described in diagnostic manuals and in line with the class of disorder that represents them.

Next, the STT of $\mathrm{C} 1$ is highlighted.

The STT of C1 is marked by the episode occurred at school, when he/she threw a chair on the floor, establishing the beginning of the bond with the CAPSi, where he/she received a diagnosis compatible with agitation and impulsivity. Initially, it was difficult for $\mathrm{C} 1$ to accept the need to attend the service, as he/she reported during the meetings that he/she did not understand the reason for being there. According to $\mathrm{C} 1$, the service was for children with mental problems, but, gradually, he/she got used to the routine of consultations with the reference technique, but not with the use of medication, because it bothered his having to take it every day.

It should be noted that, for $\mathrm{C} 1$, the construction of a good therapeutic bond with the reference technique ensured that he was able to understand the need to participate in individual care, given that he/she received encouragement to develop a competitive profile and had difficulty in dealing with frustrations. Finally, the child reached the understanding of how this care helped to control his/her insecurity and anxiety at school and also at home.

When questioning $\mathrm{C} 1$ about situations that cause anxiety, it becomes noticeable, in his/her speech, that the possible cause of episodes of insecurity and anxiety experienced by $\mathrm{C} 1$ is related to an external cause due to witnessing conflicts between parents.

The therapeutic trajectory, represented by Figure 2, also reveals an emblematic life story marked by a transit in the health and social assistance network. The path taken indicates significant disruptions in relation to the family from the shelter situations. These disruptions were necessary due to the permanence of $\mathrm{C} 2$ on the streets.

For this participant, the STT starts with the follow-up at the CAPSi in the municipality where she was born. This early start in the therapeutic follow-up was due to the family situation related to drug use. After the separation of the parents, mother and daughter moved to another municipality where C2 resumed monitoring at CAPSi.

The family situation of $\mathrm{C} 2$ became quite complex with the worsening of the economic and social vulnerability, since the mother was unemployed, and staying on the streets required protective measures for shelter, which were present during the construction of the STT. However, on the other hand, C2 resented being away from family and friends, as she reported the desire to leave the shelter soon, a fact that

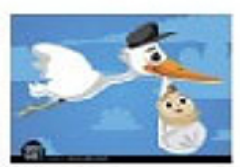

Born in 2006

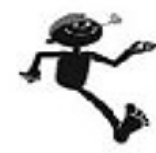

Joined the CAPSi

in 2012
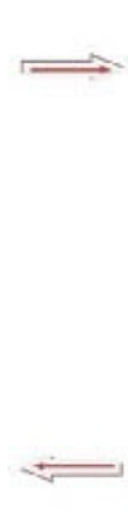

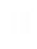

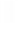

\section{Show}

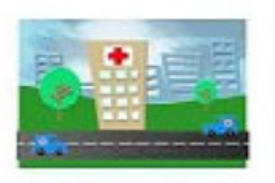

Santa Casa

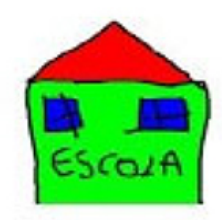

at school
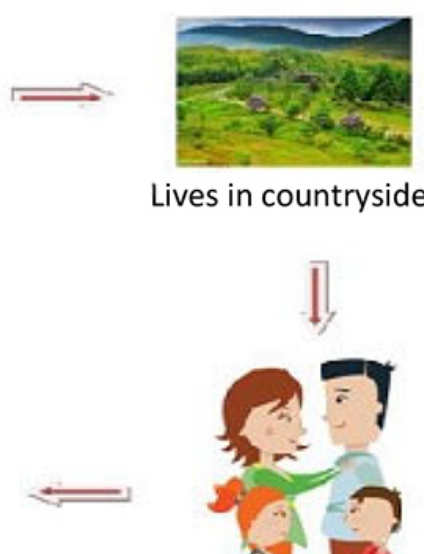

Lives in countryside

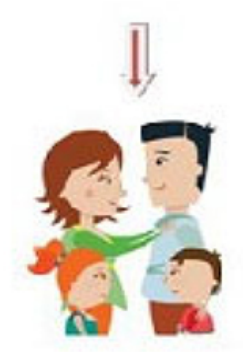

Family nucleus

Figure 1 - Therapeutic trajectory of Child 1 (C1), RS, Brazil, 2017

Source: Authors. 


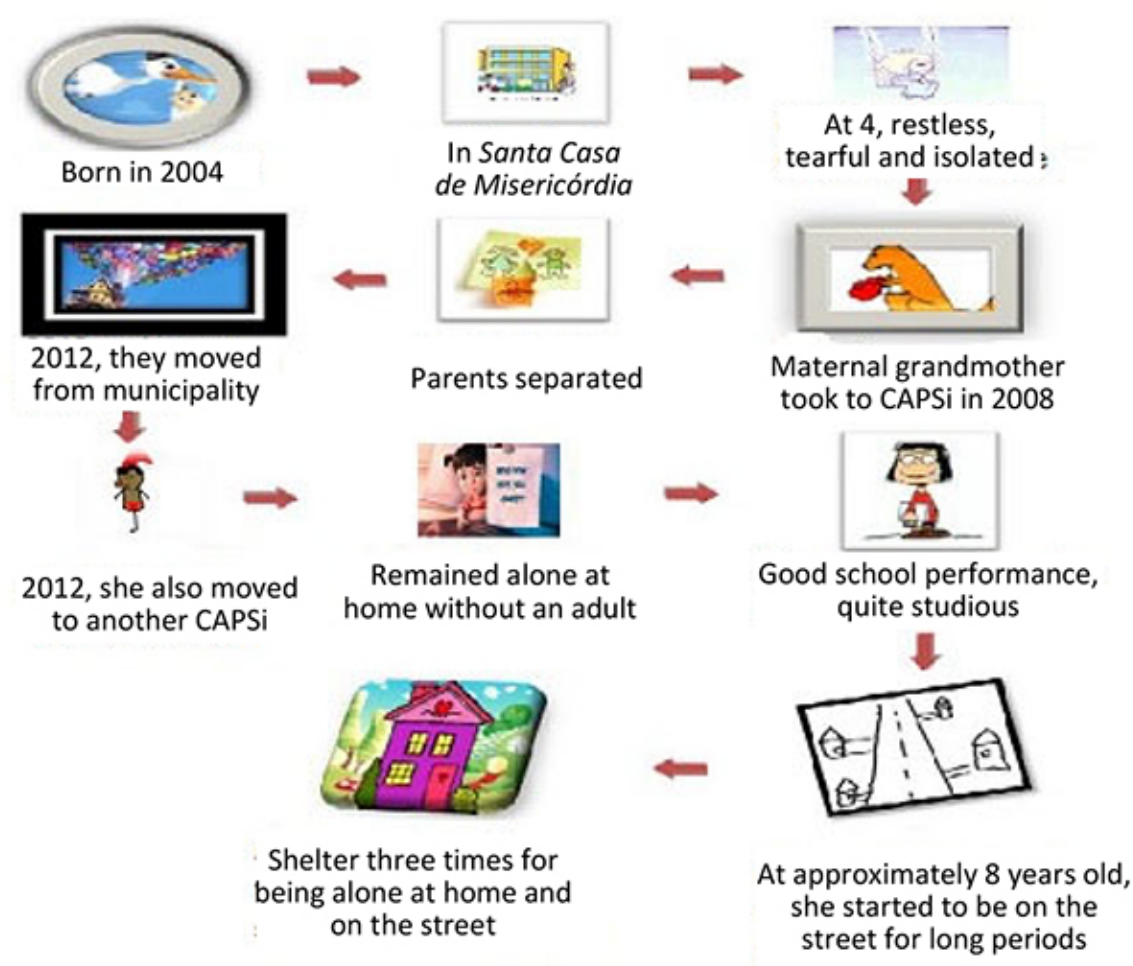

Figure 2 - Therapeutic trajectory of Child 2 (C2), RS, Brazil, 2017

Source: Authors.

extended after the end of the collection. Another reason for discomfort for $\mathrm{C} 2$ was the use of medication for enuresis. She reported that the use made her sleepy to go to school and that she did not want to be called "crazy" for attending the CAPSi and also having to use medication. Her diagnosis was established from the following symptoms: agitation, hyperactivity and changes in mood.

It is possible to perceive that the family bond is considered, by participant C2, as the main source of social and affective support, despite the situation of shelter and neglect to which he/she was exposed.

Participant C3 has a STT marked by many separations and rapprochements with her family. As shown in Figure 3, the participant's delivery was performed at the Basic Health Unit, as there was no time to transport her to Santa Casa de Misericórdia. According to the mother's report, they were fine and only spent one night in the hospital so that C3's mother could recover. When C 3 was just one year old, the child moved in with her maternal great-grandmother and grandmother, as her mother moved to another house. When C3 was two years old, the maternal grandmother also left the city and went to live in another municipality.

C3 started her care in the CAPSi at a very young age. At the age of three, the child was referred by the nursery school due to hyperactivity, as she was tearful in different situations and had enuresis both at night and during the day. The child had difficulty socializing and sexualized behavior. When contradicted, she self-aggrieved, throwing himself/herself on the floor and struggling. The family relationship was very difficult, both with the maternal figure, who imposed many physical punishments on him/her, and with the father, who was always distant from the reality experienced by $C 3$ due to his involvement with drugs.

There were judicial orders for the family to resume care, as C3 evaded the service at times, as the family did not maintain regular monitoring. The diagnosis for $\mathrm{C} 3$ was established by the symptoms observed: agitation, crying, nervousness, day and night enuresis.

Figure 4 shows the STT of participant C4, who lived with his/her mother and sisters on a stilt on the banks of a river. The stepfather worked in the countryside, but returned home every 15 days. The father was in seclusion due to the crimes he had committed, and his/her relationship with his/her father was fragile due to his withdrawal. The school made a referral to the service due to the agitation presented in the classroom, low concentration and because it only recognized the letter "A" and was unaware of the other vowels, consonants and numbers. 


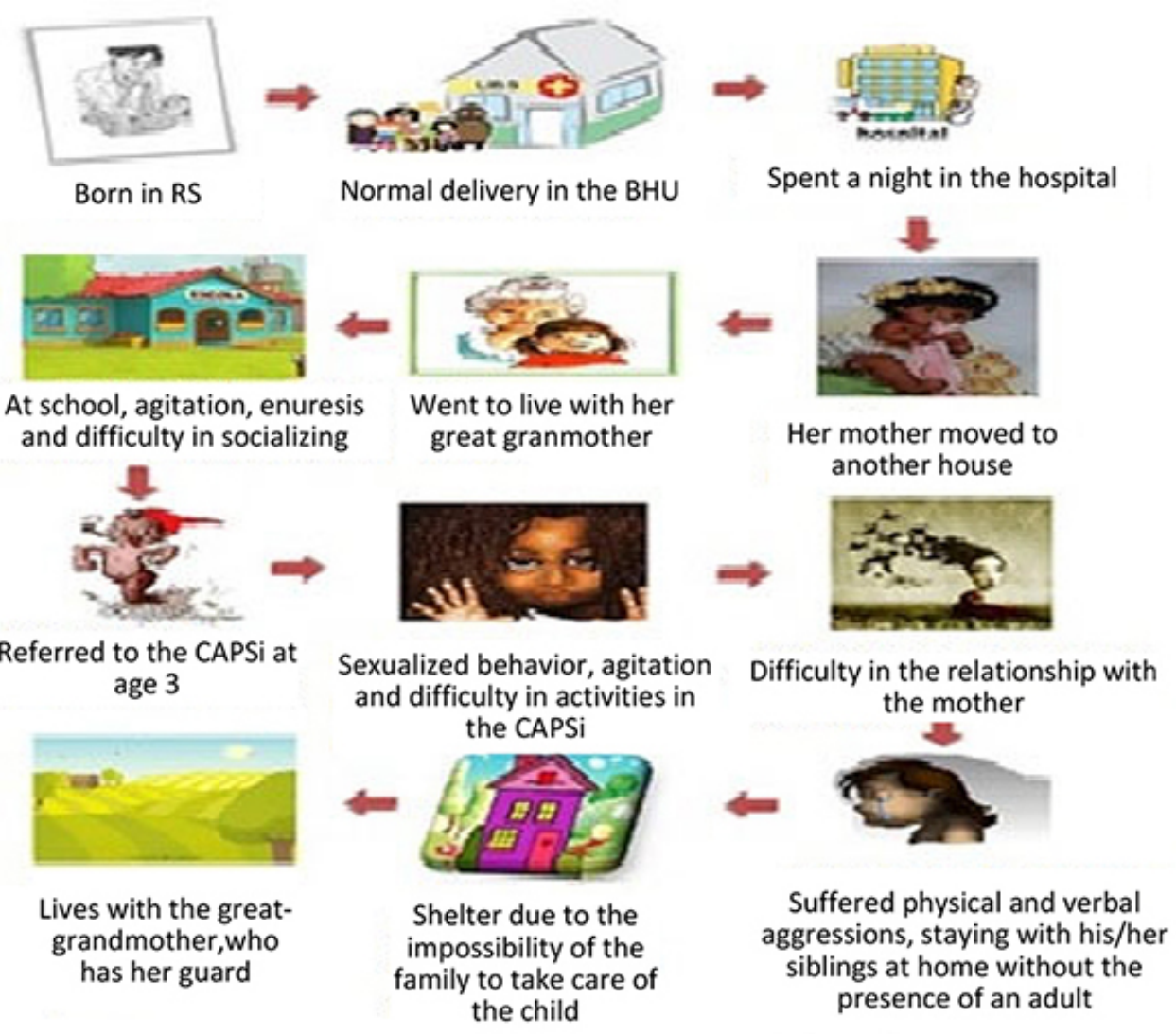

Figure 3 - Therapeutic trajectory of Child 3 (C3), RS, Brazil, 2017 Source: Authors.

Among the participants, C4 was the only one who was not using any psychiatric medication, his/her services were performed by the pedagogue and his/her school performance had improved significantly after the start of the follow-up in the CAPSi. However, the child evaded the service during the mother's pregnancy, since they used to go to the service on foot and, for this reason, she was unable to take the child to consultations and activities due to the distance from the residence.

The STT of participant C5, as shown in Figure 5 .

The referral of $\mathrm{C} 5$ to the CAPSi was via school due to some factors, among them, the difficulty of the teachers in dealing with their high cognitive skills, as he/she demonstrated great capacity for understanding and, for this reason, performed the tasks with great precision and, generally, in less time than other colleagues.

This required that the school be pedagogically prepared to deal with and offer activities that would meet C5's demands, making it clear that the school, when referring him/ her to the service, was unable to meet his/her needs.
The difficulty in family management with C5 also contributed to his/her permanence in the CAPSi, as the family had some socioeconomic and also psychosocial limitations. During the meetings, it was noticed that this situation was observed by the parents: the child's early intellectual development in relation to other children and also to themselves.

At the age of four, C5 taught himself/herself to read and write, showing high skills. He/She helped the mother regarding the hours related to the organization of the house. C5's father is the family member who most closely follows his/her path through services. It is him who takes the child to all the consultations and activities in the CAPSi and in the CRAS. C5's mother also did a follow-up in the CAPS due to mental disability.

Describing this trajectory was very disturbing due to the reality of life of a child who, with high cognitive abilities, obtained in response to his/her needs a type of assistance in a service for the care of severe mental suffering and his/her diagnosis was established based on episodes of agitation 


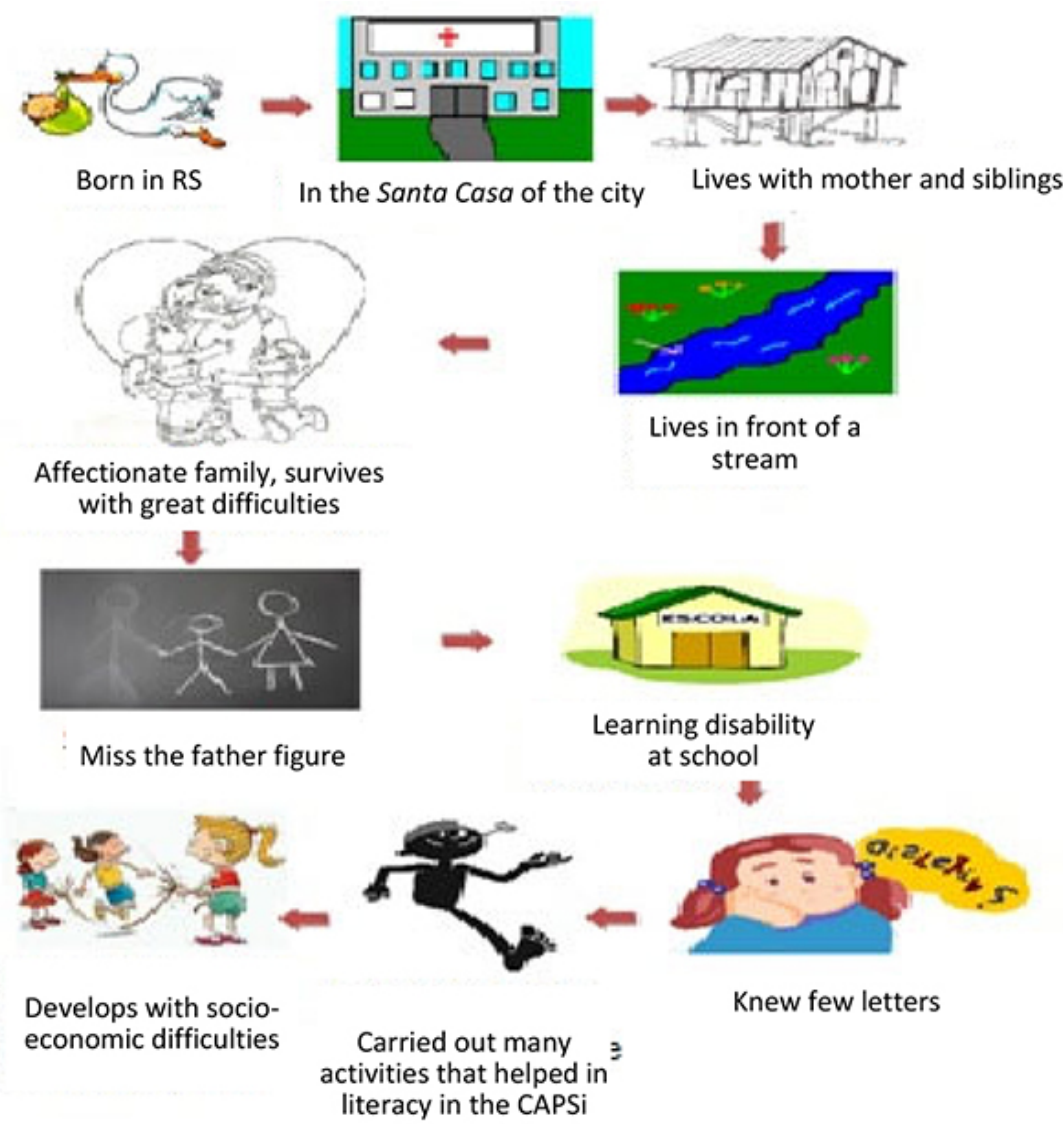

Figure 4 - Therapeutic trajectory of Child 4 (C4), RS, Brazil, 2017 Source: Authors.

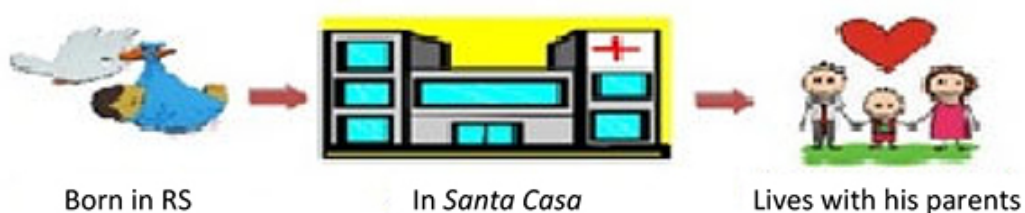

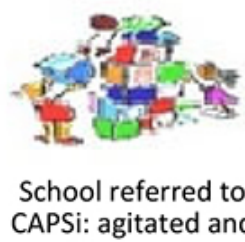

CAPSi: agitated and self-aggressive

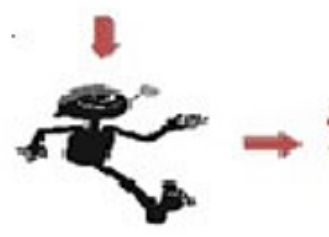

Has a good bond with reference technique

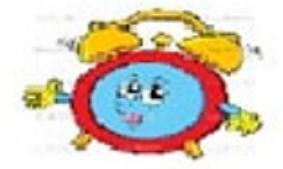

Helped the family with the schedules

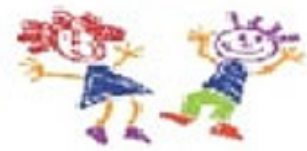

Good relation with neighbour

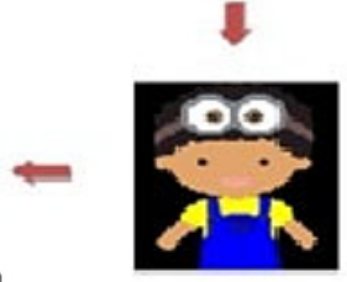

At the age of three he learned alone how to read and write

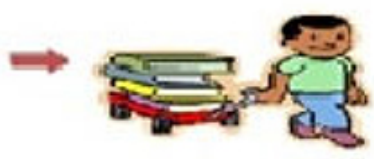

Extremely organized with his books

Figure 5 - Therapeutic trajectory of Child 5 (C2), RS, Brazil, 2017 
and irritation. In addition to the consultations, C5 did not escape the prescription of a psychotropic drug to control his/her emotions and impulses. Throughout the meeting to conduct the interview, it became clear that the promotion of his/her skills and potential needs other places in addition to the CAPSi.

\section{DISCUSSION}

The experiences lived and narrated by the children about their STTS, in the search for care spaces, considering the family, the CAPSi and the school, enabled the identification of the potentialities and difficulties of locating and using the resources that are available in their territories. In this work, the use of the figures approached children's knowledge about their trajectories with images, without the intention of superimposing them on their narratives, but to complement them, giving meaning to research that promotes child protagonism ${ }^{(3-4)}$.

The STTs favored the promotion of child protagonism and allowed the children to talk about their fears in relation to the family organization and their anxieties related to the deprivation of basic rights, such as food and their relation with medication, with emphasis on the STTs of C1, C2 and C5, respectively.

For $\mathrm{C} 1$, the beginning of the bond with the CAPSi enabled the understanding of the need to be cared for in a place that she idealized as a place for children with mental problems, revealing the stigma that exists around those who attend the Mental Health service ${ }^{(7,14)}$. For this reason, it was necessary to construct images that represented the participants in addition to the psychiatric diagnoses, their crises and the outbreaks described in their medical records $s^{(2,4)}$.

The shelter situation in the STT of C2 during the research would require a more effective work by other professionals who could also take responsibility, as they play a role in mental health care in different places, such as the Basic Health Units, school, family, friends and neighbors, breaking with a practice that thinks that psychosocial care is only performed in the CAPSi(4).

In the STTS of $\mathrm{C} 2, \mathrm{C} 3$ and $\mathrm{C} 4$, evasion of the service was observed for different reasons: C4 evaded due to the distance from his/her residence to the service, while $\mathrm{C} 2$ and $\mathrm{C} 3$ presented difficulties in family organization. These situations are related to the existential dimension of the territory ${ }^{(5,7)}$. Based on this information and on the understanding of the political conception of the territory, the CAPSi will be able to actively search for them to promote the continuity of essential care for psychosocial rehabilitation ${ }^{(3)}$.

In the STTS, the active search for the participants means a political attitude of work in tune with the integrality of care, leading to evasion as a health need ${ }^{(4,7)}$.

It should also be noted that the Psychiatric Reform Movement, which underlies this study, makes it possible to expand discussions on the process of psychological distress and care practices ${ }^{(7,15)}$. Thus, the STTs allow discussing the different forms of exclusion still present in the discourses on pathologization. The justification for medicalization is still restricted to the diagnoses of $\mathrm{C} 1, \mathrm{C} 2, \mathrm{C} 3$ and $\mathrm{C} 5$ that were in their medical records, that this practice is justified by the child's unwanted behavior at school, at home, on the street, in the places where they go, only for the biological issue, without questioning the social situation in which they are subjected ${ }^{(2-3)}$.

The social construction of pathologization of the child is historically related to the discourses produced about childhood, which follow the political and economic characteristics over time ${ }^{(16)}$ and affect the family and school places explicit in the STTs described in this work ${ }^{(3)}$. From the STTs, it is possible to question the extent to which there are only pathological issues to avoid the ideological support of exclusion ${ }^{(6)}$.

The little recognition about the participants' life context, related to the social processes experienced about violence and poverty, allows for misunderstandings about their mental health condition, since the consequences of the STTS reveal that anxiety-promoting situations are caused by external circumstances related to the social problems faced by the families of $\mathrm{C} 1, \mathrm{C} 2, \mathrm{C} 3, \mathrm{C} 4$ and $\mathrm{C} 5^{(6,16)}$.

It is noticed that there is an effort, on the part of the CAPSi reference technicians, to promote changes in the children's emotional situation, however, not all the participants ( $\mathrm{C} 1, \mathrm{C2}$ and C3) were linked to the workshops and only C4 and C5 participated in the group activities. This need was observed, both for children and family members, as a preventive measure against violence $e^{(14,16-17)}$.

The STTS ${ }^{(1-2)}$ can be built from choices and achievements that happen in everyday life. This dynamic, established in the context of relations, challenges to understand the different aspects and singularities of children, since they are learning and developing certain autonomy to perform their social roles with their family and friends. However, in the context of children, it is understood that their choices and achievements are still controversial when situations of physical, psychological, sexual violence and neglect are part of everyday life ${ }^{(17)}$. 
These data are important to keep in mind regarding the interface between education and health, and the need for an articulation between schools and Mental Health services, considering production of health and the culture of care offered to children. Health is linked to the context of culture, as well as it is closely related to the context of health. Both are essential when it comes to preserving and promoting the healthy development of children ${ }^{(3-4,12)}$.

\section{GINAL CONSIDERATIONS}

The description of the therapeutic trajectories made it possible to present the uniqueness of life of the research participants through the relation established between the child, the territory where he/she transits and the social context. It was noticed that one of the challenges of the work carried out by the CAPSi is to break with the existing hegemonic discourse and practices and often legitimized by the network: family, CAPSi and school.

The research presented some limits in relation to the sample and to the time of data collection. Related to the latter, it is believed that a longer time with the children, who did not present so many details in the narrative, would favor the complementation of the therapeutic trajectories, since a greater approximation favors the bond and the dialog and that would demand a time over the collection period. Another important limitation is related to the small sample size of children, as it was realized that more children could benefit from the space built during the research, strengthening the need to incorporate the knowledge of the singular therapeutic trajectories in the daily service network.

As a contribution to the research, teaching and assistance, the singular therapeutic trajectories enabled the (re) construction of the path taken by the children, in order to find and outline network care strategies, guaranteeing quality health and well-being rights of children in the context where they live, as they shed light which potentials and weaknesses were present in the relations established.

Thus, the results found originate from the children's narratives and the need is understood for further studies that contemplate the knowledge of the children's singular therapeutic trajectories as a possibility to analyze their life background, in order to collaborate for the improvement of the mental health of children and adolescents, as well as for the researchers and the public policies.

\section{REFERENCES}

1. Cardoso CS. Trajetórias terapêuticas e as redes sociais e afetivas das crianças que frequentam o Centro de Atenção Psicossocial Infantojuvenil [dissertação]. Pelotas (RS): Universidade Federal de Pelotas; 2017 [citado 2019 abr 10]. Available from: https://wp.ufpel.edu.br/pgenfermagem/files/2017/03/Disserta\%C3\%A7\% C3\%A30-Clarissa-de-Souza-Cardoso.pdf

2. Norozi SA, Torill M. Childhood as a social construction. J Educ Soc Res. 2016 [cited 2019 Feb 10]:6(2):75-80. Available from: https://www.mcser.org/ journal/index.php/jesr/article/viewFile/9151/8837

3. Couto MCV, Delgado PGG. Crianças e adolescentes na agenda política da saúde mental brasileira: inclusão tardia, desafios atuais. Psicol Clín. 2015;27(1):17-40. doi: https://doi.org/10.1590/0103-56652015000100002

4. Silveira A0, Bernardes RC, Wernet M, Pontes TB, Silva AA0. Family's social support network and the promotion of child developement. REFACS. 2016 [cited 2019 Mar 27];4(1):6-16. Available from: http://seer.uftm.edu.br/revistaeletronica/ index.php/refacs/article/view/1528/1321

5. Santos M, Silveira ML. O Brasil: território e sociedade no início do século XXI. $18^{\mathrm{a}}$ ed. Rio Janeiro: Record; 2014.

6. Amarante P, Nunes MO. Psychiatric reform in the SUS and the struggle for a society without asylums. Ciênc Saúde Coletiva. 2018;23(6):2067-74. doi: https://doi.org/10.1590/1413-81232018236.07082018

7. Vasconcelos FG, Cartaxo CMB. Saúde mental em rede: uma análise de território. ECOS: Estud Contemp Subjet. 2016 [citado 2019 mar 10];6(1):113-24. Disponível em: http://www.periodicoshumanas.uff.br/ecos/article/view/1846

8. Minayo MCS. Amostragem e saturação em pesquisa qualitativa: consensos e controvérsias. Rev Pesq Qualitativa. 2017 [citado 2019 fev 25]:5(7):1-12. Disponível em: https://editora.sepq.org.br/index.php/rpq/article/view/82/59

9. MuylaertCJ,SarubbiJrV,GalloPR, Rolim Neto ML, Reis AOA. Narrative interviews:an importantresource in qualitative research. RevEscEnferm USP.2014;48(esp.2):1939. doi: https://doi.org/10.1590/50080-623420140000800027

10. Pereira VR, Coimbra VCC. Cardoso CS, Oliveira NA, Vieira ACG, Nobre MO, et al. Participatory methodologies in research with children: creative and innovative approaches. Rev Gaúcha Enferm. 2016;37(esp):e67908. doi: https://doi. org/10.1590/1983-1447.2016.esp.67908

11. Carlos DM, Pádua EMM, Ferriani MGC.Violence against children and adolescents: the perspective of Primary Health Care. Rev Bras Enferm. 2017;70(3):511-8. doi: https://doi.org/10.1590/0034-7167-2016-0471

12. Monteiro ACS, Fernandes ATRS, Oliveira ABM, Peixoto IVP, Pamplona MCCA. Mothers' perspective on violence against children: constructing meanings. Rev Bras Enferm. 2018;71(1):34-9. doi: https://doi.org/10.1590/ 0034-7167-2016-0568

13. Ministério da Saúde (BR), Conselho Nacional de Saúde. Resolução 466, de 12 de dezembro de 2012. Diretrizes e normas regulamentadoras de pesquisas envolvendo seres humanos. Diário Oficial da União [da] República Federativa do Brasil. 2013 jun13; 150(112 seção 1):59-62.

14. Tszesnioski CL, Nóbrega KB, Lima ML, Dutra FVL. Building the mental health care network for children and adolescents: interventions in the territory. Ciênc Saúde Coletiva. 2015;20(2):363-70. doi: https://doi.org/10. 1590/1413-81232015202.05082014 
15. Calza TZ, Dell'Aglio DD, Sarriera JC. Direitos da criança e do adolescente e maus-tratos: epidemiologia e notificação. Rev SPAGESP, 2016 [citado 2019 fev 15]:17(1):14-27. Disponível em: http://pepsic.bvsalud.org/scielo.php?script= sci_arttext\&pid=S1677-29702016000100003

16. Bastos IT, Sarubbi Jr V, Oliveira TGP, Delfini PSS, Muylaert CJ, Reis AOA. Identity of care in a psychosocial care center for children and adolescents who uses drugs. Rev Esc Enferm USP. 2014;48(2):121-7. doi: https://doi.org/10.1590/ S0080-623420140000800018

17. Gonçalves CFG, Silva LMP, Pitangui ACR, Silva CC, Santana MV. Network action for the care of adolescent victims of violence: challenges and possibilities. Texto Contexto Enferm. 2015;24(4):976-83. doi: https://doi. org/10.1590/0104-0707201500004580014

\section{Acknowledgment:}

To the Coordination for the Improvement of Higher Level Personnel (Coordenação de Aperfeiçoamento de Pessoal de Nivel Superior, (APES) for having financed the research through resources spent through a scholarship, to the Center for Psychosocial Care for Children and Adolescents (Centro de Atenção Psicossocial Infantojuvenil, CAPSi) for collaborating to develop the research, especially the service team who assisted the researcher in the search for medical records and bonds with the children. To the Research Group on Mental Health and Public Health for the opportunity to deepen studies and improve research with children.

\section{- Corresponding author:}

Clarissa de Souza Cardoso

E-mail: cissascardoso@gmail.com

\section{Associate editor:}

